\title{
Pengembangan Panduan Bimbingan Kelompok dengan Teknik Fun Outbound untuk Meningkatkan Perilaku Altruis Siswa Sekolah Menengah Pertama
}

\author{
(Establishment of Group Counselling Guidelines using Fun Outbond Technique to \\ Enhance Junior High School Students' Altruism)
}

\author{
Hanifan Ahadinasrikin, Henny Indreswari*, M. Muslihati \\ ${ }^{1}$ Universitas Negeri Malang, Jl. Semarang No. 5 Malang, Jawa Timur, Indonesia \\ *Penulis korespondensi, Surel: henny.indreswari.fip@um.ac.id
}

Paper received: 2nd-Oct-2020; revised: 30th-Jan-2021; accepted: 10th-Mar-2021

\begin{abstract}
This research and development seek to construct a group counseling guideline book with a fun outbound strategy to increase junior high school students' generosity. The product was designed following the research and development procedure from Borg and Gall. The analysis results of data from guidance and counseling experts, media experts, and users validity present that this guideline is applicable to be used according to its accuracy, usability, easiness, and attractiveness. During the product validation phase, altruism and product eligibility instruments were used. The obtained data included quantitative and qualitative data. The quantitative data were analyzed using the inter-rater agreement model, while the qualitative data were analyzed by concluding the subjects' rating. The complete product's validity score shows that this counseling guideline is feasible to be used by schools' counselors in the group counseling addressed to enhance junior high school students' altruism.
\end{abstract}

Keywords: fun outbound technique; altruism; junior high school student

\begin{abstract}
Abstrak
Penelitian dan pengembangan ini bertujuan menghasilkan buku panduan bimbingan kelompok dengan teknik fun outbound untuk meningkatkan perilaku altruis siswa sekolah menengah pertama (SMP). Produk ini dikembangkan sesuai dengan prosedur penelitian dan pengembangan model Borg dan Gall. Berdasarkan hasil analisis data penelitian, validasi ahli materi bimbingan dan konseling, validasi ahli media, dan calon pengguna produk serta uji kelompok kecil dapat disimpulkan bahwa buku panduan bimbingan kelompok dengan teknik fun outbound untuk meningkatkan perilaku altruis siswa SMP tepat digunakan sesuai dengan aspek keberterimaan (ketepatan, kegunaan, kemudahan, dan kemenarikan). Pada tahap validasi produk peneliti menggunakan instrumen perilaku altruis dan instrumen keberterimaan produk. Data yang diperoleh berupa data kuantitatif dan data kualitatif. Data kuantitatif dianalisis menggunakan inter-rater agreement model. Sedangkan data kualitatif dianalisis dengan menyimpulkan hasil penilaian dari subjek uji coba. Berdasarkan penilaian dari keseluruhan validasi produk, panduan bimbingan ini layak dan dapat digunakan konselor sekolah dalam memberikan layanan bimbingan kelompok untuk meningkatkan perilaku altruis siswa SMP.
\end{abstract}

Kata kunci: teknik fun outbound; altruis; siswa SMP

\section{Pendahuluan}

Altruis merupakan suatu perbuatan yang dilakukan oleh seseorang untuk membantu dan menolong orang lain tanpa memikirkan kepentingan diri sendiri. Lebih tepatnya pada pengertian yang sederhana altruis dapat disamakan dengan perilaku menolong orang lain. Perilaku altruis merupakan lawan dari perilaku egois, yang diartikan sebagai perilaku yang 
hanya memikirnya dirinya sendiri tanpa memikirkan orang lain. Altruis adalah kebalikan dari egois, orang yang altruis yaitu orang yang peduli untuk menolong orang lain tanpa mengharapkan imbalan atas pertolongan yang dilakukan (Myers, 2012). Pendapat lain menyatakan bahwa altruis adalah tindakan yang dilakukan oleh seseorang atau sekelompok orang untuk menolong orang lain tanpa mengharapkan imbalan apapun (Sears, Peplau, \& Taylor, 2009). Dapat diartikan bahwa perilaku altruis terjadi bilamana seseorang ketika berinteraksi sosial melihat orang yang kesusahan ia akan dengan senang hati untuk membantu orang yang sedang kesusahan tersebut. Keinginan untuk membantu orang tersebut didasari adanya rasa empati sehingga seseorang akan dengan sukarela dalam membantu orang lain tanpa mengharapkan imbalan apapun.

Setiap individu perlu memiliki perilaku altruis untuk menciptakan kerukunan sosial antar sesama, saling bertukar pikiran dan saling memahami satu sama lain, serta menjalin fungsi kehidupan sebagai makhluk sosial (Koppel, Andersson, Västfjäll, \& Tinghög, 2017; Vinayak \& Judge, 2018). Sejalan dengan pernyataan tersebut, Batson menjelaskan bahwa seseorang yang altruis memiliki empati terhadap orang lain untuk meringankan penderitaan orang lain, mencegah terjadinya agresi (Myers, 2012). Seseorang yang altruis cenderung pemaaf dan tidak suka dengan kekerasan serta mampu bekerjasama dengan orang lain. Dalam kenyataan, perilaku altruis masyarakat cukup rendah. Rendahnya perilaku altruis juga terjadi pada jenjang sekolah menengah. Salah satu contoh akibat dari rendahnya sikap altruis siswa sekolah menengah pertama (SMP) kekerasan pelajar di SMPN 1 Desa Paduraksa, Kecamatan Sikap Dalam, Kabupaten Empat Lawang, Sumatra Selatan pada Februari 2019. Pada peristiwa tersebut, salah satu siswa meninggal. Hal ini dikarenakan selisih paham karena saling mengejek sehingga terpancing terjadinya perkelahian. Ketika perkelahian tersebut berlangsung respon siswa yang lain, bukan melerai melainkan membantu mengeroyok korban hingga akhirnya korban meninggal. Hal demikian, menjadi potret yang negatif dalam bidang pendidikan (Zulkanedy, 2019).

Sebuah penelitian menunjukkan bahwa beberapa perilaku yang menunjukkan rendahnya perilaku altruis adalah: tidak memperhatikan guru yang sedang menjelaskan, siswa malah sibuk sendiri dengan teman sebangkunya, dan ketika pulang sekolah ada siswa yang berkelahi, tetapi teman yang lainnya tidak melerainya malah hanya diam diri tidak menolong bahkan meninggalkannya (Isnaeni, Wibowo, \& Mugiarso, 2018). Fenomena tersebut juga terjadi di SMP Negeri 1 Dawarblandong, Kecamatan Dawarblandong-Mojokerto. Sebagian besar siswa menunjukkan rendahnya perilaku altruis yang ditandai dengan rendahnya empati siswa pada saat jam pelajaran di kelas. Ketika guru sedang menjelaskan materi, para siswa sibuk berbicara dengan teman sebangkunya. Pada saat berdiskusi, beberapa siswa juga terlihat memotong pembicaraan teman lainnya dan mau menang sendiri atas pendapatnya ketika berdiskusi. Peneliti juga menjumpai beberapa siswa yang tidak membaur dengan teman yang lain atau bisa disebut dengan geng. Setelah pulang sekolah ketika di tempat parkir sepeda, peneliti melihat dari beberapa siswa yang kurang peduli antar sesama ditunjukkan dengan sebagian siswa hanya diam dan melihat saja teman yang sedang kesulitan karena ban sepedanya bocor dan kesulitan untuk mengeluarkan sepedanya dari tempat parkir.

Siswa yang duduk di bangku sekolah di tingkat SMP berada pada usia belasan tahun ini termasuk ke dalam fase remaja awal. Masa remaja merupakan masa individu yang berada pada proses perubahan menuju kematangan kedewasaan secara fisik, emosional, dan sosial. berada pada awal masa remaja berlangsung. Remaja awal sebagai masa periode peralihan, status 
individu tidaklah jelas dan terdapat keraguan atas peran yang dilakukan. Ketidakjelasan status dan keraguan yang dialami oleh remaja awal membuat remaja harus mencari identitas diri dan penyesuaian diri dengan kelompok teman sebaya. Pada saat remaja mencari identias diri dengan penyesuaian diri terhadap standar kelompok, seperti halnya yang telah ditunjukkan diantaranya dalam hal berpakaian, berbicara, berperilaku seperti teman-teman dalam kelompok tersebut. Selama remaja mencari identitas diri, terjadi perubahan-perubahan yang dialami oleh remaja baik berupa perubahan fisik, sikap, ataupun perilaku. Perubahanperubahan yang terjadi pada remaja akan mempengaruhi perilaku. Karena perubahan tersebut remaja merasa mandiri dalam mengatasi masalah, namun pada akhirnya menemukan bahwa penyelesaian masalah yang dihadapi tidak selalu sesuai dengan harapan remaja. Berdasarkan fenomena yang telah diuraikan sebelumnya, rendahnya perilaku altruis pada siswa SMP karena kurangnya pemahaman mengenai peranan dalam berhubungan sosial yaitu kesadaran akan tanggungjawab sosial.

Rendahnya perilaku altruis dapat ditingkatkan lewat bimbingan kelompok (Mesa, Aspin, \& Rudin, 2020). Layanan bimbingan kelompok diharapkan tepat memberikan kontribusi terhadap peningkatan perilaku altruis siswa, karena dalam pelaksanaan bimbingan kelompok, anggota kelompok akan bersama-sama menciptakan dinamika kelompok yang dapat dijadikan tempat untuk mengembangkan perilaku altruis. Di samping itu, anggota kelompok mempunyai hak yang sama untuk melatih diri dalam mengemukakan pendapat, membahas masalah pentingnya berperilaku altruis terhadap orang lain, dapat saling bertukar pengalaman dan informasi, serta memberikan saran kepada anggota kelompok lain. Selain itu, melalui bimbingan kelompok mampu mengembangkan keterampilan untuk mengidentifikasi tanggungjawab/tingkah laku yang layak bagi penyesuaian diri dengan lingkungannya. Adapun teknik yang dapat menjadi alternatif dalam peningkatan perilaku altruis tersebut yaitu dengan teknik fun outbound.

Fun outbound merupakan jenis kegiatan outbound yang merujuk pada kegiatan di alam terbuka yang tidak terlalu menekan unsur fisik yang kuat (Arachchige \& Thisara Sathsara, 2020). Karena kegiatan yang sifatnya dilakukan di luar ruangan peserta akan lebih aktif dan mampu mengekpresikan sikap dan perilakunya. Dikatakan menyenangkan karena dilakukan di luar ruangan dan menyatu dengan alam. Fun outbound memiliki berbagai bentuk kegiatan, seperti permainan, diskusi, simulasi, bermain peran, dan asah otak melalui teka-teki. Bentuk kegiatan berupa simulasi kehidupan sosial melalui permainan-permainan kelompok yang tidak terlalu menekan pada unsur fisik, akan tetapi mampu menggabungkan ketiga aspek (kognitif, afektif, dan psikomotor) yang bertujuan untuk meningkatkan keterampilan sosial, seperti kepedulian sosial, kemampuan bekerjasama, dan membangun karakter yang positif. Perilaku altruis juga merupakan salah satu bentuk keterampilan sosial.

Melalui permainan dalam fun outbound, akan terjadi kontak sosial guna mengembangkan kemampuan dalam berinteraksi individu dengan teman sebaya sebagai pengajaran aktif perilaku altruis. Hal demikian, akan menunjang aspek psikomotor dalam mengembangkan perilaku altruis. Melalui permainan siswa dihadapkan dengan permasalahan-permasalahan, rintangan-rintangan yang menuntut peserta terampil dalam berinteraksi sosial. Dengan kegiatan bermain semua aspek kognitif, afektif, dan psikomotor berfungsi secara optimal sehingga dapat merangsang kemampuan penalaran siswa. Fun outbound juga telah digunakan dalam beberapa penelitian sebelumnya (Helmawati, 2015). Hasil penelitian tersebut menunjukkan bahwa fun outbound efektif digunakan untuk meningkatkan perilaku asertif siswa. 
Selain itu, permainan dalam fun outbound juga dapat digunakan untuk meningkatkan motivasi (Dimyati \& Aminah, 2017), meningkatkan sistem motorik (Dimyati \& Aminah, 2017), perkembangan sosial (Yeni \& Aulia, 2019), sampai kematangan emosional (Pratama \& Hudah, 2020).

Dari beberapa penelitian yang telah dijelaskan sebelumnya, keunggulan dari teknik fun outbound merupakan kegiatan yang sangat cocok dalam pengembangan pribadi maupun kelompok, dan juga disenangi oleh semua kalangan baik dari anak-anak, remaja hingga dewasa. Selain itu, kegiatan fun outbound memiliki ciri khas tersendiri jika dibandingkan dengan lainnya, dimana keseluruhan kegiatan dirancang dalam bentuk pengalaman secara langsung yang dilakukan di alam terbuka dalam situasi yang relaks dan santai. Proses pengalaman tersebut akan membekali diri dalam menghadapi kehidupan sosial secara nyata. Berdasarkan uraian permasalahan yang telah dijelaskan serta mengingat bahwa begitu besar manfaat bimbingan kelompok melalui kegiatan fun outbound dalam meningkatkan perilaku altruis pada siswa, tujuan penulisan artikel ini adalah mengembangkan panduan bimbingan meningkatkan perilaku altruis siswa dengan teknik fun outbound. Produk hasil pengembangan tersebut berupan panduan yang dapat digunakan sebagai acuan konselor sekolah dalam memberikan layanan bimbingan dan konseling kepada siswa melalui fun outbound sebagai teknik layanan agar lebih menarik dan cepat dipahami.

\section{Metode}

Penelitian ini mengadaptasi model penelitian dan pengembangan Borg dan Gall (1984). Tahapan dalam model pengembangan dan penelitian ini meliputi: (1) studi pendahuluan dan pengumpulan data awal, (2) perencanaan, (3) pengembangan bentuk awal produk, (4) validasi produk yang dilakukan oleh subjek validator ialah ahli materi bimbingan dan konseling (BK), ahli media, dan uji calon pengguna produk dan uji lapangan terbatas (uji kelompok kecil) di SMPN 1 Dawarblandong, Kab. Mojokerto, (5) Revisi produk akhir berdasarkan penilaian dan saran dari subjek uji coba.

Pada tahap perencanaan, peneliti mulai menyusun latar belakang, rencana tujuan penelitian dan pengembangan, spesifikasi produk yang diharapkan, kriteria keberterimaan produk dan kisi-kisi angket keberterimaan produk, pentingnya penelitian dan pengembangan, asumsi dan keterbatasan penelitian dan pengembangan, definisi operasional, kajian teori serta menyusun kisi-kisi pengembangan produk. Pada tahap ini, peneliti sudah memiliki gambaran umum mengenai kebutuhan siswa akan layanan bimbingan dengan tema peningkatan perilaku altruis siswa SMPN 1 Dawarblandong.

Selanjutnya, pada tahap pengembangan bentuk awal produk disesuaikan dengan spesifikasi produk yang telah dijabarkan pada tahap kedua. Pada tahap ini peneliti membuat buku panduan bimbingan kelompok dengan teknik fun outbound yang akan digunakan sebagai media dalam meningkatkan perilaku altruis siswa, serta menyusun angket keberterimaan produk dan angket skala perilaku altruis. Angket keberterimaan produk yang digunakan oleh subjek uji coba untuk memberikan penilaian terhadap produk yang dibuat oleh peneliti pada tahap uji coba produk, sedangkan angket skala perilaku altruis akan diberikan kepada siswa untuk need assessment selanjutnya yang dapat memperkuat hasil wawancara dan observasi mengenai kebutuhan siswa pada tahap pertama. Pemberian instrumen perilaku altruis siswa dilakukan pada tahap ketiga sebelum melaksanakan uji coba produk. 
Tahap keempat yang dilakukan oleh peneliti ialah validasi produk. Validasi produk dilakukan oleh subjek uji coba, yaitu ialah ahli materi BK, ahli media pembelajaran, dan uji calon pengguna produk, serta uji lapangan terbatas. Subjek uji coba memberikan penilaian kepada produk yang telah dibuat oleh peneliti berdasarkan instrumen keberterimaaan dan lembar saran perbaikan yang telah dibuat oleh peneliti. Pada tahap validasi produk diperoleh dua jenis data yaitu data kuantitatif dan data kualitatif. Data kuantitatif dianalis menggunakan interrater agreement model atau nilai kesepakatan antar rater. Sedangkan data kualitatif dianalisis menggunakan analisis deskriptif dengan menyimpulkan hasil penilaian komentar dan saran perbaikan yang diberikan oleh subjek uji coba.

Tahap kelima merupakan tahap terakhir dalam prosedur penelitian dan pengembangan. Pada tahap ini, peneliti melakukan revisi akhir pada panduan bimbingan dengan teknikfun outbound. Revisi atau perbaikan ini dilakukan berdasarkan kesimpulan dari penilaian dan saran subjek oleh uji coba. Revisi ini bertujuan dalam penyempurnaan produk panduan bimbingan sehingga lebih layak digunakan untuk mencapai tujuan penelitian.

\section{Hasil dan Pembahasan}

\subsection{Hasil}

Hasil penelitian dan pengembangan ini berupa buku panduan bimbingan kelompok dengan teknik fun outbound untuk meningkatkan perilaku altruis siswa SMPN 1 Dawarblandong. Buku panduan ini ditujukan kepada konselor SMPN 1 Dawarblandong sebagai acuan dalam memberikan layanan bimbingan kelompok dengan teknik fun outbound guna meningkatkan perilaku altruis siswa SMPN 1 Dawarblandong. Buku panduan bimbingan ini terbagi menjadi tiga bagian yaitu: Bagian I pendahuluan, yang memuat rasional bimbingan, tujuan dan sasaran, peran konselor dan siswa, serta metode dan teknik yang digunakan selama proses bimbingan. Pada bagian II petunjuk pelaksanaan, yang berisikan uraian penjelasan tujuan umum dan tujuan khusus mengenai rambu-rambu pelaksanaan yang memberikan kemudahan konselor dalam melaksanakan kegiatan fun outbound. Pada petunjuk pelaksanaan juga dijelaskan bagaimana memberikan instrumen skala perilaku altruis yang digunakan untuk mengukur tingkat perilaku altruis siswa. Sedangkan pada bagian III prosedur bimbingan, berisikan uraian prosedur pelaksanaan bimbingan dalam peningkatan perilaku altruis siswa. Prosedur bimbingan terbagi menjadi empat pertemuan. Masing-masing pertemuan memiliki tujuan dan sasaran yang berbeda. Pencapaian tujuan dan sasaran dirancang secara sistematis melalui rencana pelaksanaan layanan bimbingan dan konseling (RPLBK).

Panduan bimbingan juga dilengkapi dengan instrumen evaluasi yang digunakan untuk mengukur dan mengetahui ketercapaian tujuan pada beberapa aspek. Pada aspek kognitif menggunakan beberapa pertanyaan sesuai dengan pengetahuan yang telah diberikan. Pada aspek afektif melalui refleksi diri, apa yang dirasakan oleh siswa setelah diberikan layanan bimbingan. Sedangkan aspek psikomotor melalui pretest dan posttest melalui inventori perilaku altruis. Selain itu, panduan juga dilengkapi dengan lampiran sebagai penunjang uraian pada setiap bagian yang dapat digunakan oleh konselor untuk lebih memahami materi yang diuraikan dalam panduan.

Data penelitian meliputi hasil uji ahli materi BK, ahli media, calon pengguna produk dan uji kelompok terbatas (uji kelompok kecil). Data penelitian dan pengembangan ini berupa data kuantitatif dan data kualitatif. Penilaian dari ahli materi bimbingan dan konseling 
menunjukkan indeks skor sebesar 1 yang artinya produk pengembangan ini sangat layak untuk digunakan. Penilaian dari ahli media menunjukkan indeks skor sebesar 0,8 yang artinya produk pengembangan ini sangat layak untuk digunakan. Selanjutnya diperoleh indeks skor sebesar 1 dari calon pengguna produk (konselor sekolah). Sedangkan hasil data penilaian dari uji kelompok kecil yang berjumlah 15 siswa SMPN 1 Dawarblandong terhadap pelaksanaan bimbingan, diperoleh indeks skor sebesar $100 \%$ yang berarti pelaksanaan bimbingan sangat memenuhi aspek keberterimaan, sehingga interpretasi dari penilaian tersebut menyatakan bahwa teknik fun outbound sangat layak digunakan dalam memberikan layanan bimbingan kelompok untuk mengembangkan perilaku altruis siswa. Berdasarkan hasil tersebut artinya produk panduan bimbingan sangat layak digunakan konselor dalam memberikan layanan.

\subsection{Pembahasan}

Perilaku altruis adalah suatu tindakan yang dilakukan oleh seseorang atau sekelompok orang untuk membantu dan menolong orang lain tanpa mengharapkan imbalan apapun (Fehr \& Fischbacher, 2003; Piccinini \& Schulz, 2019). Perilaku altruis penting dimiliki siswa SMP untuk menciptakan kerukunan sosial antar sesama, saling bertukar pikiran, dan saling memahami satu sama lain, serta menjalin fungsi kehidupan sebagai makhluk hidup. Terlebih siswa SMP berada pada masa peralihan (transisi) dari masa anak-anak menuju masa dewasa. Pada masa peralihan ini siswa mengalami banyak sekali dihadapkan dengan penyesuaian sosial yang sulit, dikarenakan kuatnya pengaruh teman akan mempengaruhi pola perilaku, minat, serta nilai-nilai yang diyakininya. Rendahnya perilaku altruis yang terjadi pada siswa SMP karena belum tercapainya tugas perkembangan yang dialamu oleh siswa SMP atau remaja awal.

Tugas yang dicapai pada masa remaja yang berkaitan dengan penyesuaian sosial ialah mencapai hubungan baru dan lebih matang dengan teman sebaya, mencapai peranan sosial laki-laki dan perempuan, dan mencapai perilaku sosial yang bertanggungjawab (Jackson \& Goossens, 2020). Dengan demikian perlu adanya keterampilan sosial yang dilatihkan kepada siswa agar siswa dalam mencapai tugas perkembangan secara optimal. Perilaku altruis merupakan salah satu bentuk keterampilan sosial (Bereczkei, Birkas, \& Kerekes, 2010) yang sangat esensial yang dimiliki oleh siswa sebagai dorongan dalam berperilaku prososial (Simpson \& Willer, 2015). Salah satu alternatif untuk meningkatkan perilaku altruis siswa melalui kegiatan fun outbound.

Fun outbound adalah bentuk kegiatan bimbingan yang dilakukan di alam terbuka melalui diskusi, permainan, simulasi, bermain peran, dan asah otak yang menyenangkan dan tidak membutuhkan peralatan yang banyak sebagai bentuk simulasi kehidupan, sehingga mampu merangsang minat dan keinginan siswa dalam meningkatkan keterampilan sosial. Melalui permainan dalam fun outbound, akan terjadi kontak sosial dilakukan untuk mengembangkan kemampuan dalam berinteraksi dengan teman sebaya sebagai pengajaran aktif perilaku altruis. Hal demikian, akan menunjang aspek psikomotor dalam mengembangkan perilaku altruis. Permainan yang digunakan tidak memperdulikan hasil akhir dari permainan itu sendiri, melainkan yang lebih penting adalah proses bermain itu sendiri, bagaimana siswa mengamati model yang dilakukan teman sebaya dalam pengajaran perilaku altruis tersebut saat bermain. Setelah mengamati akan muncul respon dari peserta lain untuk meniru pengajaran yang dilakukan oleh model untuk dilakukan oleh peserta. Sehingga dapat diartikan bahwa permainan merupakan bagian penting dalam proses perkembangan sosial siswa 
(Charlop, Lang, \& Rispoli, 2018; Goldstein \& Lerner, 2018; Joaquim, da Silva, \& Lourenço, 2018).

Melalui permainan, siswa dihadapkan dengan permasalahan-permasalahan, rintanganrintangan yang menuntut peserta terampil dalam berinteraksi sosial. Dengan kegiatan bermain semua aspek kognitif, afektif, dan psikomotor berfungsi secara optimal sehingga dapat merangsang kemampuan penalaran siswa. Dapat diketahui bahwa bermain adalah aktivitas yang menyenangkan. Bermain merupakan kegiatan yang dapat menimbulkan kesenangan bagi anak, dengan kegiatan tersebut anak mendapatkan kebahagiaan dan kegembiraan (Elfiadi, 2016). Untuk itu peneliti menggunakan teknik fun outbound agar siswa tidak cepat bosan.

Produk panduan bimbingan ini dinilai layak dan tepat untuk meningkatkan perilaku altruis siswa SMP sesuai dengan aspek keberterimaan (ketepatan, kegunaan, kemudahan, dan kemenarikan). Hal demikian, karena panduan telah teruji secara teoritis dan praktis melalui penilaian dari ahli materi bimbingan dan konseling, ahli media pembelajaran, calon pengguna (konselor), dan uji lapangan terbatas pada kelompok kecil yang memberikan sangat baik terhadap panduan.

Hasil dari uji lapangan terbatas (kelompok kecil) juga menunjukkan hasil yang baik. dibuktikan dengan siswa terlibat aktif dan antusias, serta bersemangat mengikuti layanan bimbingan hingga selesai. Pada lembar evaluasi juga menunjukkan bahwa siswa mampu menjawab sejumlah pertanyaan yang diajukan terkait dengan layanan bimbingan. Selain itu, pada indeks skor pada inventori perilaku altruis juga menunjukkan peningkatan yang artinya panduan bimbingan kelompok dengan teknik fun outbound ini sangat layak digunakan untuk meningkatkan perilaku altruis siswa SMP.

Penelitian ini juga melalukan perbaikan sesuai saran dan masukan oleh ahli materi bimbingan dan konseling, ahli media pendidikan, calon pengguna (konselor), dan uji lapangan terbatas (uji kelompok kecil). Panduan ini diharapkan membantu konselor dalam memberikan layanan bimbingan kelompok denga teknik fun outbound untuk meningkatkan perilaku altruis siswa SMP.

\section{Simpulan}

Penelitian dan pengembangan ini menghasilkan buku panduan bimbingan kelompok dengan teknik fun outbound untuk meningkatkan perilaku altruis siswa yang dapat digunakan oleh konselor sekolah dalam memberikan layanan. Panduan bimbingan ini dapat diterima kelayakannya dan sangat layak digunakan sebagai alternatif layanan bimbingan dan konseling, serta menarik minat siswa untuk mengikuti layanan. Terkait hasil penelitian, konselor sekolah disarankan mempelajari dan memahami prosedur pelaksanaan bimbingan ini agar proses pemberian layanan dapat berjalan dengan lancar dan efektif. Peneliti selanjutnya dapat menguji keefektifan produk pengembangan ini

\section{Daftar Rujukan}

Arachchige, U. S. P. R., \& Thisara Sathsara, K. L. (2020). The impact of outbound training (Obt). International Journal of Scientific and Technology Research, 9(4), 377-380.

Bereczkei, T., Birkas, B., \& Kerekes, Z. (2010). Altruism towards strangers in need: costly signaling in an industrial society. Evolution and Human Behavior, 31(2), 95-103.

Borg, W. R., \& Gall, M. D. (1984). Educational research (4th ed). New York: Longman. 
Charlop, M. H., Lang, R., \& Rispoli, M. (2018). More than just fun and games: Definition, development, and intervention for children's play and social skills. In Play and social skills for children with autism spectrum disorder (pp. 1-16). Springer.

Dimyati, A., \& Aminah, A. S. (2017). Pengaruh fun outbound untuk meningkatkan motivasi siswa dalam mengikuti pembelajaran penjas pada siswa kelas XI di SMK Yisca Cilamaya Karawang. Seminar Nasional Riset Inovatif, 5, 153-158.

Elfiadi, E. (2016). Bermain dan permainan bagi anak usia dini. ITQAN: Jurnal Ilmu-Ilmu Kependidikan, 7(1), 5160.

Fehr, E., \& Fischbacher, U. (2003). The nature of human altruism. Nature, 425(6960), 785-791.

Goldstein, T. R., \& Lerner, M. D. (2018). Dramatic pretend play games uniquely improve emotional control in young children. Developmental Science, 21(4), e12603.

Helmawati, A. (2015). Pengaruh fun outbound dalam meningkatkan perilaku asertif anak yatim di Griya Yatim Desa Perak. Universitas Islam Negeri Maulana Malik Ibrahim Malang.

Isnaeni, N., Wibowo, M. E., \& Mugiarso, H. (2018). Meningkatkan perilaku altruisme pada siswa sekolah menengah pertama (SMP) melalui konseling kelompok. Indonesian Journal of Guidance and Counseling: Theory and Application, 7(1), 45-51.

Jackson, S., \& Goossens, L. (2020). Handbook of adolescent development.

Joaquim, R. H. V. T., da Silva, F. R., \& Lourenço, G. F. (2018). The make-believe and games as an intervention strategy for an infant with delay in child development. Cadernos de Terapia Ocupacional Da UFSCar, 26(1), 63-71A.

Koppel, L., Andersson, D., Västfjäll, D., \& Tinghög, G. (2017). The (null) effect of affective touch on betrayal aversion, altruism, and risk taking. Frontiers in Behavioral Neuroscience, 11, 251.

Mesa, N. M. R., Aspin, A., \& Rudin, A. (2020). Pengaruh layanan bimbingan kelompok terhadap perilaku altruisme siswa. Jurnal Ilmiah Bening: Belajar Bimbingan Dan Konseling, 4(1), 35-44.

Myers, D. G. (2012). Psikologi sosial. Jakarta: Salemba Humanika.

Piccinini, G., \& Schulz, A. W. (2019). The ways of altruism. Evolutionary Psychological Science, 5(1), 58-70.

Pratama, N. Y., \& Hudah, M. (2020). Pendekatan permainan outbound sirkuit game dalam meningkatkan kematangan emosional dan spitual melalui pembelajaran penjas pada siswa SMP N 1 Sumowono. Journal of Sport Coaching and Physical Education, 5(1), 8-13.

Sears, D. O., Peplau, L. A., \& Taylor, S. E. (2009). Psikologi sosial. Jakarta: Kencana Prenada Media Group.

Simpson, B., \& Willer, R. (2015). Beyond altruism: Sociological foundations of cooperation and prosocial behavior. Annual Review of Sociology, 41, 43-63.

Vinayak, S., \& Judge, J. (2018). Impact of altruism and forgiveness on empathy among police personnel. Impact: International Journal of Research in Humanities, Arts and Literature, 6(2), 167-176.

Yeni, R. A., \& Aulia, P. (2019). Efektivitas kegiatan outbound fun estafet untuk meningkatkan perkembangan sosial anak di Taman Kanak-Kanak Al-Jannah Tarusan Kabupaten Pesisir Selatan. SELING: Jurnal Program Studi PGRA, 5(2), 161-168.

Zulkanedy, B. (2019). Pelajar SMP tewas dalam duel maut lawan teman sekelas. 